\title{
Jejunal mucosal morphology in healthy north Indian subjects
}

\author{
MK BENNETT, ${ }^{*}$ GK SACHDEV,$\dagger$ DP JEWELL,${ }^{*}$ BS ANAND $\dagger$ \\ From the Departments of Gastroenterology, *John Radcliffe Hospital, Headington, Oxford, and †GB Pant \\ Hospital, New Delhi
}

SUMMARY Morphometric measurements have been performed on small intestinal biopsy specimens obtained from 18 healthy adult Indian volunteers. The measurements were made using a computer aided measuring system, and results were similar to those previously reported for an adult Caucasian population.

Histological abnormalities of the jejunal mucosa have been noted in a high proportion of apparently healthy asymptomatic subjects living in developing countries, especially in the tropics.' ${ }^{\prime}$ These findings are often accompanied by malabsorption of two or more unrelated substances; this syndrome is known as subclinical tropical enteropathy (STE). The mucosal abnormalities seen in STE are qualitatively similar to those seen in tropical sprue but of a milder degree, ${ }^{23}$ which suggests a possible relation between these two conditions. ${ }^{4}$ In India, tropical sprue runs a milder course in the north compared with the southern part of the country, ${ }^{5}$ where the disease is not only more severe but also has an epidemic form. ${ }^{6}$ Over $90 \%$ of the healthy subjects in southern India have morphological abnormalities of the jejunal mucosa, ${ }^{7}$ and it is possible that the severity of tropical sprue is related to the high prevalence rate of mucosal changes in the normal population. To examine this jejunal mucosal biopsy specimens were obtained from asymptomatic volunteers in New Delhi (north India) and the results were compared with a similar western population.

\section{Subjects and methods}

Eighteen healthy volunteers consisting of medical students, resident doctors, and nurses were included in the study. The group was chosen since it had similar standards and conditions of hygiene to a western population, enabling comparison with morphological studies from western and Indian countries. There were 14 men and four women in the age range of 18 to 28 years $($ mean $(S D)=24 \cdot 33(2 \cdot 39))$. Informed consent was obtained from each volunteer.
After an overnight fast, a Crosby capsule was introduced and a biopsy specimen was obtained from a point just beyond the duodenojejunal junction; the position of the capsule was checked under fluoroscopy. The biopsy specimens were properly orientated over a filter paper using a dissecting microscope and then fixed in $10 \%$ formol-saline.

Further processing was carried out in Oxford, where the tissue was routinely processed to wax and multiple sections taken perpendicular to the lumen. Serial sections of $4 \mu \mathrm{m}$ were stained by haematoxylin and eosin and alcian blue/periodic acid Schiff; an average of 29 levels were examined. No obvious parasitic infestation was noted in any of the specimens. The following features were assessed: areas of the mucosa, lamina propria, and epithelium. Villous height and crypt depth in correctly orientated areas were recorded and all values were related to unit lengths of muscularis mucosae. The absolute values were obtained by calibrating the readings against a standard stage graticule measuring $2 \mathrm{~mm}$ in $0.1 \mathrm{~mm} \bigcirc$ divisions. Sections were viewed through a $10 \times \frac{I}{0}$ objective and an image was projected on to a magnetised graphic table using a camera lucida. The $N$ image was then traced manually using a cursor with cross hairs. The resolution of the table was $0 \cdot 1 \mathrm{~mm}$. ㄱ The cursor was connected to a MOP videoplan $\omega$ (Reichert-Jung UK), which is a semiautomated image analyser system, for the evaluation of these measurements and basic statistics. By means of a Leitz projecting microscope and a $40 \times$ objective + lens, an image of the mucosa was cast on to a flat surface and the epithelial cell height was measured. $\frac{\text { Pे }}{\mathbb{D}}$ This was calibrated by projecting the image of a $\frac{\rho}{\Phi}$ stage micrometer slide, with $0 \cdot 1 \mathrm{~mm}$ divisions, $\stackrel{\unrhd}{\varrho}$ measured at the beginning and end of each measuring session. The number of intraepithelial lympho- $\Omega$ 
cytes within the mucosa was calculated by a differential count of at least 600 cell nuclei; the results were expressed as intraepithelial lymphocytes per 100 enterocytes.

\section{Results}

The results were tabulated after exclusion of three biopsies from the assessment because of inadequacies of the specimens. The villous to crypt ratio was calculated from measurements of the height of the villous (from the tip of the villous to the base of the crypt) and the depth of the crypt (from the mouth to the base of the crypt). The values directly measured were within the expected range reported for adult Caucasians, (Table). Those values which were derived-that is, the volume of mucosal lamina propria and epithelium-showed differences from the values calculated by Slavin et al.$^{8}$ The ratio of epithelial volume to mucosal volume and lamina propria volume showed a greater proportion of lamina propria in this study group; the significance of this finding is unclear.

\section{Discussion}

Subclinical tropical enteropathy has been recognised in a number of underdeveloped countries. Detailed reports are available from the Indian subcontinent, ${ }^{4-11}$ Africa, ${ }^{12-14}$ the Caribbean, ${ }^{1510}$ Middle East, ${ }^{17-18}$ and south east Asia. ${ }^{14-20}$ In most studies histological abnormalities of the jejunal mucosa were seen in the majority of healthy subjects examined, from $83 \%$ to $100 \%$. In sharp contrast to the above studies, the present study found abnormal mucosa in none of the normal asymptomatic volunteers examined.

The cause of STE is uncertain, but a number of possibilities exist. Since STE is found only in the underdeveloped part of the world, nutritional deficiency may play an important part. For example, in the Caribbean, histological abnormalities are most severe in residents of Haiti, who have a poor diet compared with those of Puerto Rico, whose diet is far superior and the mucosal abnormalities milder. ${ }^{15-16}$ Protein deficiency by itself, however, is not associated with histological abnormalities. ${ }^{21-23}$ Moreover, the presence of mucosal abnormalities in American peace corp workers in Pakistan, despite excellent protein intake, ${ }^{24}$ and in Europeans and Americans living in the tropics ${ }^{24} 2530$ points away from nutritional deficiency having an important aetiological role. Recurrent intestinal parasitic infestations and food toxins are other possibilities, but most workers have found no association between these and the severity of mucosal abnormalities. ${ }^{1012} 182628$

Thus the most likely possibility is an environmental factor. Visitors from temperate countries develop tropical enteropathy after arriving in the tropics. ${ }^{24}$ In a recent study from Angola $^{30}$ abnormal jejunal mucosa was seen in all the 19 Europeans examined, and the severity of the histological damage was similar to that seen in the native Africans. Moreover, the histological abnormalities are known to recover when the visitors return to their home countries. ${ }^{31}$

Similarly, the mucosal damage of STE has been shown to subside in Indian and Pakistani immigrants in America. ${ }^{14} 27$ The precise aetiological factor in the environment remains conjectural, but recurrent intestinal infection has to be considered. A study from south India reported jejunal bacterial overgrowth in eight of 12 asymptomatic subjects, ${ }^{32}$ but another study from the eastern part of the country (West Bengal) found normal bacterial flora in all 11 control subjects. ${ }^{33}$ Several worke,rs have argued in favour of recurrent subclinical enteric infections as being responsbile for the jejunal mucosal abnormalities. ${ }^{27}$

The striking difference in the jejunal morphology between residents of Delhi and those of Bombay" (western India) and Vellore (south India), where abnormalities were noted in $92 \%$ subjects each, is difficult to explain. In terms of socio-economic

Morphometric measurements of jejunal mucosa in Indian volunteers and reported normal Caucasian values

\begin{tabular}{|c|c|c|c|c|c|}
\hline & Mean & $S D$ & Range & Reported values & Reference \\
\hline Villous to crypt ratio & 3.7:1 & & & $4: 1$ & \\
\hline Villous height $(\mu \mathrm{m})$ & 523 & $( \pm 61)$ & $(432-649)$ & $386-525$ & 37 \\
\hline $\begin{array}{l}\text { Crypt depth }(\mu \mathrm{m}) \\
\text { Volume/mm }\end{array}$ & 138 & $( \pm 23)$ & $(111-185)$ & 132 & 39 \\
\hline \multicolumn{6}{|l|}{ Volume $/ \mathrm{mm}^{2}$ of muscularis mucosae } \\
\hline Mucosa & $0 \cdot 397$ & $( \pm 0.09)$ & $(0.234-0.556)$ & 0.405 & 8 \\
\hline Lamina propria & $0 \cdot 248$ & $( \pm 0.06)$ & $(0.158-0.382)$ & $0 \cdot 181$ & 8 \\
\hline Epithelium & $0 \cdot 152$ & $( \pm 0.046$ & $(0.057-0.217)$ & 0.224 & 8 \\
\hline \multicolumn{6}{|l|}{ Intraepithelial lymphocytes 100} \\
\hline enterocytes & 24 & $( \pm 7)$ & $(13-37)$ & 34 & 40 \\
\hline Epithelial cell height $(\mu \mathrm{m})$ & 34 & $( \pm 4 \cdot 67)$ & $(26 \cdot 3-40 \cdot 2)$ & $30-40$ & 42 \\
\hline
\end{tabular}


status, the volunteers tested by us were similar to those of Jeejeebhoy et al $^{4}$ : in both, the studies were carried out on doctors and nurses. Nutritional deficiency is therefore unlikely to explain the morphological differences noted between the two studies. The aetiological agent thus appears to be a factor in the environment and in this respect enteric pathogens are the strongest possibility.

The association between STE and tropical sprue is uncertain. The similarity of the mucosal abnormalities and the epidemiological distribution of the two conditions suggests a close relation. There are arguments, however, to suggest that the two are distinct entities: in Africa, STE is common but tropical sprue is rare. Similarly, STE is often seen in children, but tropical sprue is not very common.? In India, the prevalence of abnormal jejunal morphology in patients with tropical sprue varies from as high as $100 \%$ in Vellore ${ }^{34}$ to between $44 \%$ and $66 \%$ in Delhi (north India) ${ }^{35}{ }^{36}$ In this context, the observation that the jejunal mucosa of healthy control subjects is normal in north India is interesting and suggests that the milder form of tropical sprue seen here is related to a better preserved jejunal mucosa.

We conclude that STE is not as widespread and universal in the tropics as we generally believed; certainly in a north Indian city its prevalence is negligible. The aetiology of STE is almost certainly related to an environmental factor and repeated enteric infections appear to be the most likely possibility. Finally, it is tempting to ascribe the milder form of tropical sprue seen in the north to the presence of a normal jejunal mucosa in the general population.

We thank Miss $G$ Moorin for typing the manuscript and Professor JV Soames and Mr D Sale for their willing assistance and access to the MOP videoplan.

\section{References}

' Lindenbaum J. Tropical enteropathy. Gastroenterology 1973;64:637-52.

${ }^{2}$ Klipstein FA. Recent advances in tropical malabsorption. Scand J Gastroenterology 1970;suppl 6:93-114.

${ }^{3}$ Brunser O, Eidelman S, Klipstein FA. Intestinal morphology of rural Hiatians. Gastroenterology 1970;58:655-68.

${ }^{4}$ Klipstein FA. Tropical sprue-an iceberg disease? Ann Intern Med 1967;66:622-3.

${ }^{5}$ Mehta SK. Clinical features and etiopathogenesis of tropical sprue. J Assoc Physicians India 1971;19:417-24.

- Mathan VI, Baker SJ. Epidemic tropical sprue and other epidemics of diarrhoea in South Indian villages. A comparative study. J Clin Nutr 1968;21:1077-87.

${ }^{7}$ Baker SJ, Mathan VI. Tropical enteropathy and tropical sprue. Am J Clin Nutr 1972;25: 1047-55.

s Slavin G, Souter C, Robertson K, McDermott S, Paton K. Measurement of jejunal biopsies by computer aided microscopy. $J$ Clin Pathol 1980;33:254-61.
" Jeejeebhoy KN, Fesai HG, Noronba JM, Antia FP, Parekh DV. Idiopathic tropical diarrhoea with or without steatorrhoea. (tropical malabsorption syndrome). Gastroenterology 1966;51:333-44.

${ }^{10}$ Lindenbaum J, Jamiul Alam AKM, Kent TH. Subclinical small intestinal disease in East Pakistan. Br Med J 1966;ii: 1616-9.

" Banwell JH, Hutt MSR, Tunnicliffe R. Observation on jejunal biopsy in Ugandan Africans. East Afr Med J 1964;41:46-54.

${ }^{12}$ Falaiye JM. Present status of subclinical intestinal malabsorption in the tropics. $\mathrm{Br}$ Med J 1971;4:454-8.

${ }^{13}$ Rhodes AR, Shea N, Lindenbaum J. Malabsorption in asymptomatic Liberian children. Am J Clin Nutr 1971;24:574-7.

${ }^{14}$ Lindenbaum J, Harman JW, Gerson CD. Subclinical malabsorption in developing countries. Am J Clin Nutr 1972;25:105661.

${ }^{15}$ Klipstein FA, Samloff IM, Smarth G, Schenk E. Malabsorption and malnutrition in rural Hiati. Am $J$ Clin Nutr 1968;21:1042-52.

${ }^{16}$ Klipstein FA, Beauchamo I, Corcino JJ, et al. Nutritional status and intestinal function among rural population of the West Indies. II Barria Nuovo, Puerto Rico. Gastroenterology 1972;63:758-67.

17 Parkins RA, Eidelman S, Perri SB, Rubin CE. A preliminary study of factors affecting blood lipid levels in three groups of Yeminite Jews. Am J Clin Nutr 1966;18:134-48.

${ }^{18}$ Halsted CH, Sheis S, Sourial N, Patwardhan VN. Small intestinal structure and absorption in Egypt. Am J Clin Nutr 1969; 22:744-54.

${ }^{14}$ Sprinz H, Sribhibaadh R, Gangarosa EJ, Benyajati S, Kundel D, Halsted S. Biopsy of small bowel of Thai people with special reference to recovery from Asiatic cholera and an intestinal malabsorption syndrome. Am J Clin Pathol 1967;38:43-51.

${ }^{20}$ Colwell EJ, Welsh JD, Legters LJ, Proctor RF. Jejunal morphological characteristics in South Vietnamese residents. J Am Medical Assoc 1968;206:2273-6.

${ }^{21}$ Gough KR, Read AE, McCarthy CF, Water AH. Megaloblastic anaemia due to nutritional deficiency of folic acid. $Q J$ Med 1963;32:243-56.

22 Jenson H, Jarnum S, Hart Hansen JP. Gastrointestinal protein loss and intestinal function in nephrotic syndrome. Nephron 1966;3:209-20.

${ }^{23}$ Marin GA, Clark ML, Senior JR. Studies of malabsorption occurring in patients with Laennec's Cirrhosis. Gastroenterology 1969;56:727-36.

${ }^{24}$ Lindenbaum J. Small intestinal dysfunction in Pakistan and American residents in Pakistan. Am $J$ Clin Nutr 1968;21:1023-9.

${ }^{25}$ Thomas G, Clair DJ, Wicks ACB. Tropical enteropathy in Rhodesia. Gut 1976; 17:888-94.

${ }^{26}$ Cook GC, Kajubi SK, Lee FD. Jejunal morphology of the African in Uganda. J Pathol 1969;98:157-69.

${ }^{27}$ Garson CD, Kent TH, Saha JR, et al. Recovery of small intestinal structure and function after residence in the tropics. II studies in Indians and Pakistanis living in New York city. Ann Intern Med 1971;75:41-8.

${ }^{28}$ Troncale FJ, Keusch GT, Miller LH. Normal absorption in Thai subjects with non specific jejunal abnormalities. $\mathrm{Br}$ Med $\mathrm{J}$ 1967;4:578-80.

${ }^{24}$ Sheehy TW. Digestive disease as a national problem IV. Enteric diseases among US troops in Vietnam. Gastroenterology 1968; 55: 105-12.

${ }^{30}$ Carneiro Chaves FJR, Velosa FT, Cruz I, et al. Subclinical tropical enteropathy in Angola: Peroral jejunal biopsy and absorption studies in asymptomatic healthy men. Mount Sinai J Med $1981 ; 48: 47-52$.

${ }^{31}$ Lindenbaum J, Gersen CD, Kent TH. Recovery of small intestinal and function after residence in the tropics. I studies in $\bigcirc$ peace corps volunteers. Ann Intern Med 1971;74:218-22.

${ }^{32}$ Bhat P, Arajan SSD, Mathan VI. Bacterial flora of the Gastrointestinal tract in South Indian control subjects and patients with 
tropical sprue. Gastroenterology 1972;62:11-21.

${ }^{33}$ Gorbach SL, Banwell JB, Jacob DM. Tropical sprue and malnutrition in West Bengal I Intestinal microflora and absorption. Am J Clin Nutr 1970;23:1545-58.

${ }^{34}$ Bhat P, Albert MJ, Rajan D, Ponneiah J, Mathan VI, Baker SJ. Bacterial flora of the jejunum: A comparison of luminal aspirate and mucosa biopsy. J Med Microbiol 1980;13:247-56.

${ }^{3 s}$ Tendon BN, Iyenger KP, Deo MG, Saraya AK. A study of sprue syndrome in adults. J Assoc Physicians India 1966;14: 197-202.

${ }^{36}$ Chuttani HK, Misra RC. Primary malabsorption syndrome in the tropics. In: Ahuja MMS, ed. Progress in clinical medicine Series 2. New Delhi: Arnold Heinemann, 1978:315-39.

${ }^{37}$ Cooke WT, Holmes GKT. Coeliac disease. Edinburgh: Churchill Livingstone, 1984:44-5.

${ }^{38}$ Myron Falchuk Z. Gluten sensitive enteropathy. Clin Gastroenterol 1983;12:475-96.
${ }^{34}$ Penna FJ, Hill ID, Kingston D, Robertson K, Slavin G, Shiner M. Jejunal mucosa morphometry in children with and without gut symptoms and in normal adults. J Clin Pathol 1981;34:386-92.

${ }^{40}$ Corazza GR, Frazzoni M, Gasbarrini G. Jejunal intraepithelial lymphocytes in coeliac disease: are they increased or decreased? Gut 1984;25: 158-62.

4 ' Ferguson A, Murray D. Quantitation of intraepithelial lymphocytes in human jejunum. Gut 1971;12:988-94.

${ }^{42}$ Lee FD, Toner PG. Biopsy pathology of the small intestine. London: Chapman and Hall, 1980:23.

Requests for reprints to: Dr MK Bennett, Department of Histopathology, Freeman Road Hospital, High Heaton, Newcastle Upon Tyne, England. 